\title{
Continuous underway measurement of microbial ectoenzyme activities in aquatic ecosystems
}

\author{
James W. Ammerman ${ }^{1, *}$, William B. Glover ${ }^{2}$ \\ ${ }^{1}$ Department of Oceanography, Texas A\&M University, College Station, Texas 77843-3146, USA \\ ${ }^{2}$ Stephen F. Austin High School, 1715 West Cesar Chavez, Austin, Texas 78703-4699, USA
}

\begin{abstract}
Microbial ectoenzyme activities in aquatic environments are important agents of polymer hydrolysis and indicators of the state of microbial carbon, nitrogen, or phosphorus nutrition. However, like most other biochemical and molecular measurements, ectoenzyme activities have been limited to discrete water samples. We have developed a continuous underway method for measuring microbial enzyme activities using high-sensitivity fluorescent substrates. The system we developed consisted of a peristaltic proportioning pump, a temperature-controlled water bath, and a spectrofluorometer interfaced to a portable computer which controlled the fluorometer and logged the data. This method has been applied to alkaline phosphatase and to leucine aminopeptidase measurements in the surface waters of the Mississippi River plume and the Louisiana shelf, and alkaline phosphatase measurements in the surface waters of a Texas lake. This method will enable us to map the surface distributions of microbial enzyme activities on scales comparable to temperature, salinity, in vivo fluorescence, and other parameters which can be continuously mapped from a research ship while underway.
\end{abstract}

KEY WORDS: Continuous-flow assay $\cdot$ Phosphatase $\cdot$ Peptidase $\cdot$ Ectoenzyme $\cdot$ Mapping

\section{INTRODUCTION}

Cell-surface or 'ectoenzymes' of aquatic microbes, together with 'extracellular' enzymes that are dissolved or absorbed to other particles than their original ones (Chrost 1991), are important catalysts in the decomposition of dissolved organic matter (DOM) and particulate organic matter (POM). Polymer hydrolysis can be the rate-limiting step in microbial DOM and POM utilization (Chrost 1994). Efficient hydrolysis and utilization of these polymers are important to the rapid microbial growth seen in many aquatic ecosystems (Azam 1998). In a review, Chrost (1990) lists 18 different microbial ectoenzymes whose activities have been measured in natural waters and sediments. This list includes phosphatases, enzymes that hydrolyze phosphate groups from organic phosphate compounds, as well as enzymes that hydrolyze polymeric carbohydrates or proteins, such as glucosidases and peptidases. Most of these ectoenzymes are found on the

*E-mail: jammer@ocean.tamu.edu cell-surface or in the periplasmic space of Gram-negative heterotrophic bacteria (Martinez \& Azam 1993b), and are common in aquatic isolates (Martinez et al. 1996). Certain ectoenzymes, such as alkaline phosphatase and leucine aminopeptidase, are also found in some species of cyanobacteria and eukaryotic phytoplankton (Martinez \& Azam 1993a, Berges \& Falkowski 1996, Gonzalez-Gil et al. 1998).

Marine studies of phosphatases using high-sensitivity fluorescent substrates date back more than $25 \mathrm{yr}$ (Perry 1972). In the last $15 \mathrm{yr}$ there has been increased interest in many different ectoenzymes in a variety of aquatic environments (Chrost 1990), particularly since the introduction of the fluorescent methylumbelliferyl and related derivatives (Hoppe 1983). These derivatives offer the advantages of low background fluorescence and are available as substrates for many different enzymes. There have also been recent improvements in the analysis methods for the fluorescent hydrolysis products, such as the use of flowinjection (Delmas et al. 1994) or of fluorescence microplate readers (Hoppe 1993, Sinsabaugh et al. 1997, 
Foreman et al. 1998). However, even though flowinjection methods have been evaluated for on-line monitoring of enzyme activities in bioreactors (Pfeiffer et al. 1992), environmental ectoenzyme assays continue to be performed with discrete samples. Studies which survey microbial ectoenzyme activities over moderate to large areas (such as the length of an estuary or throughout a coastal zone) are relatively limited (Ammerman 1991, Billen 1991, Ammerman et al. 1995, Kim 1996). However, Christian \& Karl (1995) compared the variation in $\beta$-glucosidase and leucine aminopeptidase activity in 3 major oceanic regions.

Despite all the recent progress in microbiological methods, there are still no methods for measuring bacterial biomass, activity, or growth, which can be employed continuously underway aboard ship, let alone by satellite remote sensing. Presently available bacterial growth rate measurements also involve isotopes and require tedious processing, though a non-isotopic method has recently been developed (Steward \& Azam 1999). This contrasts sharply with phytoplanktonrelated methods such as underway measurement of in vivo chlorophyll fluorescence (Lorenzen 1966), and satellite remote sensing of pigments that can be used to estimate primary production (Morel et al. 1996). Flow cytometry is now routinely used for enumeration of bacteria, cyanobacteria, and picoeucaryotes at the Hawaii Ocean Time-series site (Campbell et al. 1997) and elsewhere. Newly developed in situ flow cytometers and related instruments (Sieracki et al. 1998, Olson \& Sosik 1999) may eventually be used for in situ enumeration of bacteria and phytoplankton.

Given the convenience of the fluorescent enzyme substrates and the high activity of some enzymes in coastal environments, however, continuous underway measurement of these enzyme activities was clearly feasible. In this paper, we have demonstrated the continuous measurement of both alkaline phosphatase (AP or 'phosphatase') and leucine aminopeptidase (LAP or 'peptidase') activity in coastal water and continuous measurement of phosphatase activity in lake water. A brief account of some of this work was previously published in a Nutrient Enhanced Coastal Ocean Productivity (NECOP) workshop volume (Ammerman et al. 1995).

\section{MATERIALS AND METHODS}

The continuous-flow system that is detailed below was originally tested on lake water samples brought into the laboratory to measure phosphatase activity. The first successful field-test of this method occurred on the Sandy Creek Arm of Lake Travis, northwest of Austin, Texas, USA on 23 October 1992, aboard a lake patrol boat. Lake Travis is one of a series of lakes formed behind dams on the Colorado River. On Lake Travis, water was pumped from the surface of the lake to the continuous-flow system with a peristaltic pump, which took approximately $1 \mathrm{~min}$. Ancillary measurements made during the Lake Travis sampling included phosphate $\left(\mathrm{PO}_{4}{ }^{3-}\right)$ measured manually as soluble reactive phosphate (SRP) (Strickland \& Parsons 1972). Chlorophyll a (chl a) (and phaeopigments) were also measured by fluorescence following extraction in $90 \%$ acetone in the freezer (Strickland \& Parsons 1972), and bacterial abundance was measured by epifluorescence microscopy using acridine orange (Hobbie et al. 1977).

To date, our most extensive field use of this system has been to measure both phosphatase and peptidase activity on a NECOP cruise aboard the RV 'Longhorn'. This cruise took place from 14 to 24 July 1993, in the area of the Mississippi River plume and the northern Gulf of Mexico (Fig. 1). The Mississippi River is the largest river in the US; it drains $40 \%$ of the continental US land area (Turner \& Rabalais 1994), and accounts for up to $90 \%$ of the freshwater runoff into the Gulf of Mexico (Rabalais et al. 1996). About two-thirds of the outflow from the Mississippi River enters the Gulf of Mexico at the delta, mostly through the 4 passes labeled in Fig. 1. The remaining third of the flow comes down the Atchafalaya River and enters the Gulf through Atchafalaya Bay (Rabalais et al. 1996), also shown in Fig. 1.

When used on the RV 'Longhorn', the continuousflow system was connected to the ship's sea chest or flow-through system, which had an intake approximately $2 \mathrm{~m}$ below the surface. The time required for the water to be pumped from the intake to our apparatus averaged $3 \mathrm{~min}$. Unfortunately, no other continuous measurements were available aboard the RV 'Longhorn', such as temperature, salinity, or in vivo fluorescence.

During the 1993 Gulf of Mexico NECOP cruise, hydrographic data were acquired with a Sea-Bird Electronics CTD system and water samples were collected with a rosette sampler. Surface-water samples were generally collected with the rosette at a depth of $1 \mathrm{~m}$ or less. Though generally shallower than the $2 \mathrm{~m}$ intake for the continuous enzyme measurements, the surface samples were the closest to the continuous measurements in depth and were used for comparison (see 'Discussion'). Nutrient analyses (nitrate, nitrite, ammonium, phosphate, and silicate) were performed on board using a Technicon Autoanalyzer (Whitledge et al. 1981). Chl $a$ and bacterial abundance were determined by the methods listed above.

The impetus for developing the continuous assay came from extensive studies of phosphatase activity, including 'manual mapping' of surface activity in the Mississippi plume region of the Gulf of Mexico and fur- 
Fig. 1. Locations of 3 transects of continuous-flow ectoenzyme activity measurements from the July 1993 cruise in the northern Gulf of Mexico. The station numbers and locations are marked and the arrows indicate the direction of the ship's progress. Depth contours are shown in meters

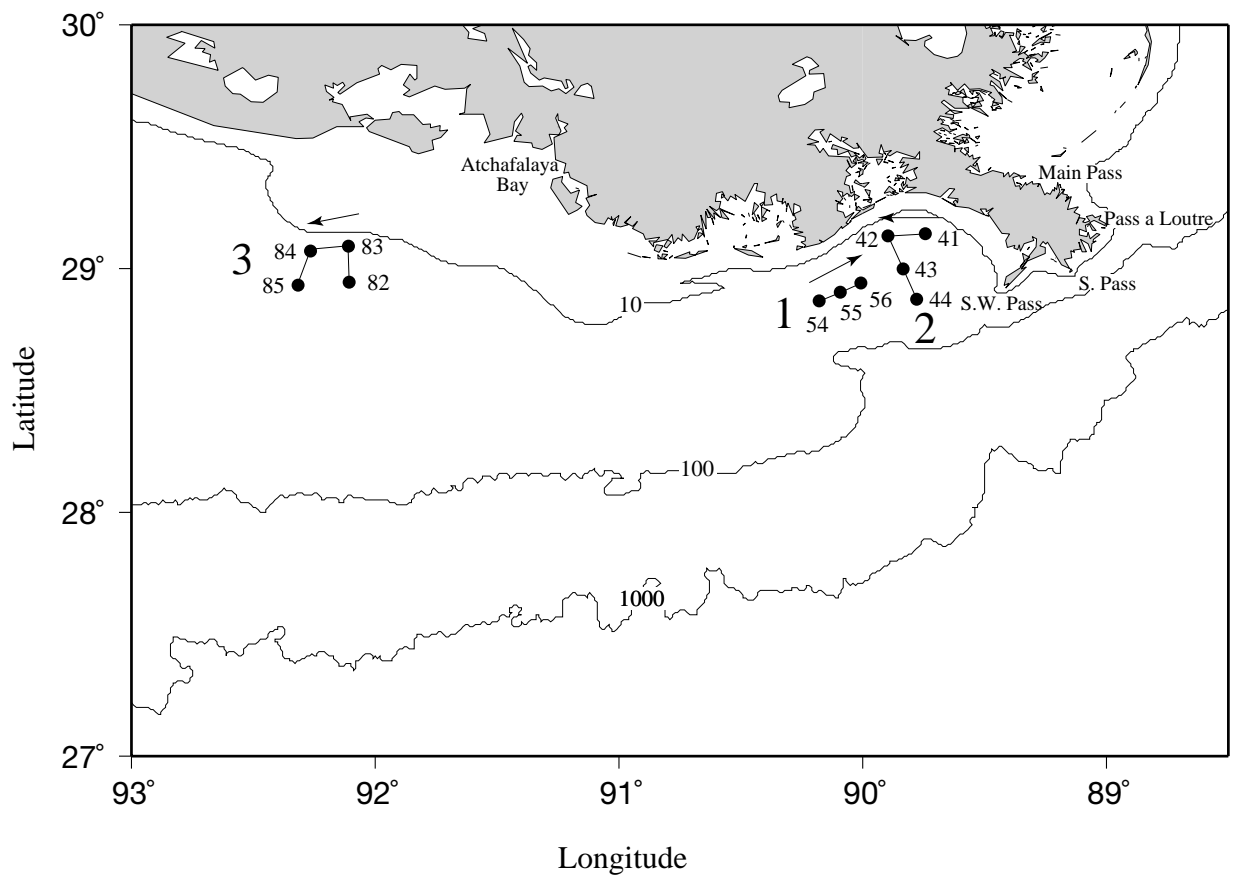

ther downstream (Ammerman et al. 1995, Kim 1996). The system we developed for continuous underway measurement of ectoenzyme activity consisted of a peristaltic proportioning pump (Technicon Autoanalyzer), a temperature-controlled water bath, and a spectrofluorometer (Shimadzu RF5000U) interfaced to a portable computer (Intel 486, Windows 3.1) which controlled the fluorometer and logged the data. The data were logged with the program SpectraCalc (Galactic Industries Corporation, Salem, NH, USA) and analyzed with the program GRAMS 386 (Galactic Industries Corporation). A circuit diagram of the plumbing for this system is shown in Fig. 2 and discussed below. When used in the field, the entire system was connected to an uninterruptible power supply (UPS) to reduce electrical noise. While this system was largely assembled from pre-existing instrumentation, including a large and expensive spectrofluorometer also used for other purposes; a dedicated portable system that would occupy about $0.5 \mathrm{~m}^{2}$ of bench space could be built for less than $\$ 20000$.

For phosphatase assays, we used the fluorescent substrate 4-methylumbelliferyl phosphate (MUF-P; Sigma Chemical Co., St. Louis, MO, USA), which yields the fluorescent product 4-methylumbelliferone after enzyme hydrolysis (excitation wavelength $360 \mathrm{~nm}$, emission wavelength $440 \mathrm{~nm}$ ). Many other enzyme substrates are also available with the same or similar fluorescent derivatives (Sigma Chemical Co.), allowing the continuous assay of many different cell-surface enzymes with this system. We also measured peptidase activity, using the related fluorescent substrate
L-leucine 7-amido-4-methylcoumarin (Leu-MCA; Sigma Chemical Co.; excitation wavelength $380 \mathrm{~nm}$, emission wavelength $440 \mathrm{~nm}$ ).

The stock substrate solutions were kept in an ice bath and shielded from light during the assay period. The substrate and sample were mixed with air bubbles and incubated in 2 coils (Coils 1 and 2, Fig. 2) immersed in a temperature-controlled water bath, which was maintained at near in situ temperature. The final substrate concentration for the automated phos-

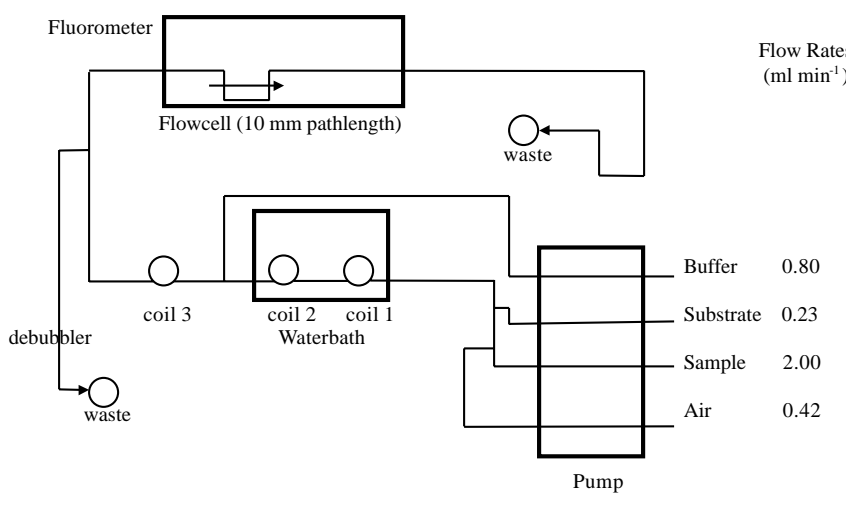

Fig. 2. Schematic circuit diagram of the automated enzyme assay system, with flow rates in $\mathrm{ml} \mathrm{min}^{-1}$. Thin lines show the path of the pump tubing, thick lines indicate the outlines of the major components. The computer (not shown) was interfaced to the fluorometer. Coils 1 and 2 were the incubation coils for the $4.5 \mathrm{~min}$ incubations but were replaced with a single longer coil for the 12.3 min incubations 
phatase assays during incubation was $1.03 \mu \mathrm{M}$ MUF-P. Manual AP assays (Ammerman 1993), including kinetics experiments, were also run on the same cruise using a Turner Model 450 digital filter fluorometer to compare with the continuous assay results. Manual assays were generally run as a 3-point time-course but calculated from 2 end points within the range of linear activity.

In order to maximize the fluorescent signal, the final substrate concentration used for the peptidase assays was $10.3 \mu \mathrm{M}$ Leu-MCA, which was the highest that could be used with this instrument configuration without excess background fluorescence. As with AP, manual peptidase assays (Ammerman 1993), including kinetics experiments, were also run on the same cruise to compare with the continuous-assay results. Manual peptidase assay conditions were the same as for the manual AP assays, only the substrate was changed. Kinetics parameters were calculated with a direct fit to a rectangular hyperbola using multiple iteration.

The incubation time with substrate in the automated system was controlled by varying the length of the incubation coils and ranged from 4.5 to $12.3 \mathrm{~min}$, but could be shorter or longer. For the 12.3 min incubation, a single long coil replaced Coils 1 and 2 (Fig. 2). The incubation should be optimized for each enzyme in each environment. For Lake Travis a 4.5 min incubation period was sufficient. This incubation time was also used in most of the Mississippi plume sampling. However for peptidase measurements and phosphatase measurements along the western Louisiana shelf, a 12.3 min incubation was necessary.

Following incubation but prior to entering the flow cell in the fluorometer, $50 \mathrm{mM}$ borate buffer (stock concentration) was mixed with air bubbles with the sample in another mixing coil in order to raise the $\mathrm{pH}$ above 10 (Coil 3, Fig. 2). This was necessary to achieve the maximum fluorescence of the methylumbelliferyl substrates (Chrost \& Krambeck 1986), though a newly available phosphatase substrate, 6,8-difluoro-4-methylumbelliferyl phosphate (Molecular Probes, Inc., Eugene, OR, USA), reportedly shows high fluorescence at neutral or slightly acidic $\mathrm{pH}$. The interval between the time that buffer was added and the sample reached the flow cell was 2.5 min; manual assays show that little additional substrate hydrolysis occurs once the $\mathrm{pH}$ has been raised. Finally the fluorescence was measured, logged in the computer, and the sample discarded.

The computer also controlled the measurement parameters of the fluorometer. The total liquid flow rate was $3 \mathrm{ml} \mathrm{min}^{-1}$ and the volume of the flow cell was $0.75 \mathrm{ml}$ with a path length of $10 \mathrm{~mm}$. The flow cell was therefore flushed every $15 \mathrm{~s}$. The individual flow rates for the different reaction components are shown in Fig. 2. Fluorescence standards (4-methylumbelliferone for AP or a related compound, 7-amino-4-methylcoumarin for peptidase) were run using the substrate tube, typically at a final concentration of about $100 \mathrm{nM}$, with the sample tube changed to deionized water. (Routine standards run in the lab with this same apparatus showed that the response was linear over a concentration range of at least 10 to $100 \mathrm{nM}$.) The substrate tube was thoroughly rinsed with deionized water following standardization. Standards were run several times a day during the cruise, but not for every section, rates were calculated using the most recent standard. For details of reagent preparation see the description of the manual phosphatase method described in Ammerman (1993).

Killed controls and turbidity blanks were run routinely in the flow-through system. Net enzyme activity was measured by the increase in fluorescence in live samples incubated with substrate over recently collected samples that had been boiled and cooled and then treated identically to live samples. Boiling was the preferred treatment for making killed controls since poisons were incompatible with the flow-through system. (These killed controls were introduced to the system through the sample line, replacing the regular live sample.) Killed controls usually had turbidity characteristics similar to samples, which controlled for any possible interactions between the substrate and sediment particles. There was no evidence for unusually high (or low) fluorescence values in the measurements of killed controls or enzyme activities in areas of high turbidity.

Turbidity blanks, which included live samples plus buffer but no substrate, were much lower than the killed controls and close to the deionized water baseline. This was true even though the turbidity was high in some areas near the delta. This shows that the major fluorescent signal from the killed controls was the substrate, the turbidity blanks were a negligible part of the total signal.

\section{RESULTS}

Hydrographic, nutrient, and biomass data collected from the Gulf of Mexico (Fig. 1) and Lake Travis are shown in Table 1. The surface waters in all the sampling areas can generally be characterized as warm and nutrient-depleted, but with moderate chlorophyll and bacterial biomass in the lake and high biomass on the Louisiana shelf. Dissolved inorganic nitrogen (DIN $=\mathrm{NO}_{3}{ }^{-}+\mathrm{NO}_{2}{ }^{-}+\mathrm{NH}_{4}{ }^{+}$) was generally below $2 \mu \mathrm{M}$ on the Louisiana shelf (not measured in Lake Travis). Dissolved inorganic phosphorus $\left(\mathrm{PO}_{4}{ }^{3-}\right)$, measured as soluble reactive phosphate that may overestimate bioavailable $\mathrm{PO}_{4}{ }^{3-}$ (Lohrenz et al. 1999), was generally 
below $0.2 \mu \mathrm{M}$ on the Louisiana shelf and below $0.1 \mu \mathrm{M}$ in Lake Travis. The highest DIN: $\mathrm{PO}_{4}{ }^{3-}$ ratios were found along Transects 1 and 2. Silicate was above $10 \mu \mathrm{M}$ along Transects 1 and 2 and lower but still above DIN along Transect 3 (data not shown). Chl a was 1 to $4 \mu \mathrm{g} \mathrm{l}^{-1}$ in Lake Travis and 4 to $22 \mu \mathrm{g} \mathrm{l^{-1 }}$ along Transects 1 and 2 on the Louisiana shelf (not measured on Transect 3). Bacterial abundance was 2 to $3 \times 10^{9} \mathrm{l}^{-1}$ in the lake and 7 to $13 \times 10^{9} \mathrm{l}^{-1}$ on the shelf (not measured on Transect 3).

The kinetics of AP and peptidase, determined by manual methods at several stations, are summarized in Table 2. Incubation times were varied with substrate concentration and activity to optimize the fluorescence response. Using MUF-P substrate concentrations from 0.01 to $10 \mu \mathrm{M}$, AP $V_{\max }$ values ranged from 0.2 to $0.5 \mu \mathrm{mol} \mathrm{l}^{-1} \mathrm{~h}^{-1}$ and $K_{\mathrm{m}}$ values from 0.2 to $0.3 \mu \mathrm{mol} \mathrm{l}^{-1}$ (Table 2). The AP activity (curves not shown) clearly reached saturation at the highest substrate concentration used $(10 \mu \mathrm{M})$. Manually measured AP activity using a $1 \mu \mathrm{M}$ MUF-P substrate concentration was $78 \pm$ $5 \%(\mathrm{n}=3)$ of the activity with $10 \mu \mathrm{M}$ substrate. Assuming that the AP kinetics were similar with the auto- mated assay system, which used a $1.03 \mu \mathrm{M}$ substrate concentration in this study, then the rates measured with the automated system should be within $20 \%$ of the maximal rates.

The peptidase substrate (Leu-MCA) concentrations used in kinetics experiments ranged from 0.1 to $10 \mu \mathrm{M}$. Peptidase $V_{\text {max }}$ values ranged from 0.04 to $0.2 \mu \mathrm{mol} \mathrm{l}^{-1}$ $\mathrm{h}^{-1}$ and $K_{\mathrm{m}}$ values from 0.7 to $4.7 \mu \mathrm{mol} \mathrm{l}^{-1}$ (Table 2). Unlike the AP activity, the peptidase activity was not clearly saturated at the maximal substrate concentration used $(10 \mu \mathrm{M})$. This suggests that the Leu-MCA concentration used for the continuous peptidase assays $(10.3 \mu \mathrm{M})$ resulted in sub-maximal peptidase activity, but higher concentrations could not be used with the available automated apparatus. Other studies have shown that $K_{\mathrm{m}}$ values for peptidase activity in aquatic environments usually exceed $10 \mu \mathrm{M}$ (Christian \& Karl 1998 and references therein, Foreman et al. 1998), and are higher than $K_{\mathrm{m}}$ values for AP (Foreman et al. 1998).

Selected transects of ectoenzyme measurements made with the automated method along the Louisiana coast are shown in Figs. 3 to 5 to illustrate the method. The locations of these Transects (1 to 3 ) are shown in

Table 1. Surface hydrographic, nutrient, and biomass data for stations along the continuous-flow enzyme assay transects. nd: no data

\begin{tabular}{|c|c|c|c|c|c|c|c|c|c|c|c|}
\hline $\begin{array}{l}\text { Transect } \\
\text { (Fig. 1) }\end{array}$ & $\begin{array}{c}\text { Stn } \\
\text { (date) }\end{array}$ & Salinity & $\begin{array}{c}\text { Temp. } \\
\left({ }^{\circ} \mathrm{C}\right)\end{array}$ & $\begin{array}{l}\mathrm{NO}_{3}^{-} \\
(\mu \mathrm{M})\end{array}$ & $\begin{array}{l}\mathrm{NO}_{2}^{-} \\
(\mu \mathrm{M})\end{array}$ & $\begin{array}{l}\mathrm{NH}_{4}{ }^{+} \\
(\mu \mathrm{M})\end{array}$ & $\begin{array}{l}\text { DIN } \\
(\mu M)\end{array}$ & $\begin{array}{c}\mathrm{PO}_{4}{ }^{3-} \quad \mathrm{D} \\
(\mu \mathrm{M})\end{array}$ & $\begin{array}{l}\mathrm{DIN}: \mathrm{PO}_{4}{ }^{3-} \\
\text { ratio }\end{array}$ & $\begin{array}{c}\text { Chl a } \\
\quad\left(\mu \mathrm{g} \mathrm{l}^{-1}\right)\end{array}$ & $\begin{array}{l}\text { Bacteria } \\
\left(\times 10^{9} \mathrm{l}^{-1}\right)\end{array}$ \\
\hline \multirow[t]{3}{*}{1} & 54 & 19.0 & 31 & 0.14 & 0.11 & 0.01 & 0.26 & 0.01 & 26 & 5.19 & 7.01 \\
\hline & 55 & 21.0 & 32 & 0.06 & 0.15 & 0.08 & 0.29 & 0.14 & 2 & 4.81 & 8.79 \\
\hline & 56 & 21.0 & 32 & 0.09 & 0.15 & 0.29 & 0.53 & 0.12 & 4 & 21.24 & 12.90 \\
\hline \multirow[t]{4}{*}{2} & 41 & 16.1 & 32 & 0.70 & 0.18 & 0.57 & 1.45 & 0.17 & 9 & 15.81 & 10.20 \\
\hline & 42 & 20.0 & 32 & 0.03 & 0.16 & 0.53 & 0.72 & 0.19 & 4 & 7.77 & nd \\
\hline & 43 & 23.0 & 31 & 2.05 & 0.14 & 2.27 & 4.46 & 0.21 & 21 & 4.10 & nd \\
\hline & 44 & 18.0 & 31 & 1.65 & 0.15 & 0.89 & 2.69 & 0.17 & 16 & 10.44 & 8.25 \\
\hline \multirow[t]{4}{*}{3} & 82 & 25.8 & 30 & 0.08 & 0.04 & 0.03 & 0.15 & 0.05 & 3 & nd & nd \\
\hline & 83 & 22.4 & 30 & 0.05 & 0.07 & 0.01 & 0.13 & 0.09 & 1 & nd & nd \\
\hline & 84 & 23.5 & 31 & 0.07 & 0.05 & 0.02 & 0.14 & 0.06 & 2 & nd & nd \\
\hline & 85 & 26.2 & 31 & 0.07 & 0.05 & 0.04 & 0.16 & 0.02 & 8 & nd & nd \\
\hline Lake Travis & $(10 / 23 / 92)$ & nd & $25-26$ & nd & nd & nd & nd & $0.02 \pm 0.02$ & $2^{\mathrm{a}}$ nd & $2.78 \pm 0.33^{a}$ & $2.32 \pm 0.34^{\mathrm{a}}$ \\
\hline${ }^{\mathrm{a}}$ Mean $\pm 1 \mathrm{SL}$ & $\mathrm{n}=14$ & & & & & & & & & & \\
\hline
\end{tabular}

Table 2. Kinetics of akaline phosphatase (AP) and peptidase in the Gulf of Mexico determined by manual assays

\begin{tabular}{|c|c|c|c|c|c|c|}
\hline Enzyme & Stn & Location & $\begin{array}{c}\text { Substrate } \\
\text { concentration }(\mu \mathrm{M})\end{array}$ & $\begin{array}{l}\text { Incubation } \\
\text { time (min) }\end{array}$ & $\begin{array}{c}V_{\max } \\
\left(\mu \operatorname{mol~l} l^{-1} \mathrm{~h}^{-1}\right)\end{array}$ & $\begin{array}{c}K_{\mathrm{m}} \\
\left(\mu \mathrm{mol} \mathrm{l} \mathrm{l}^{-1}\right)\end{array}$ \\
\hline $\mathrm{AP}$ & 39 & $28^{\circ} 57.5^{\prime} \mathrm{N}, 89^{\circ} 38.5^{\prime} \mathrm{W}$ & $0.01-10$ & $12-40$ & 0.5 & 0.3 \\
\hline AP & 51 & $28^{\circ} 41.3^{\prime} \mathrm{N}, 90^{\circ} 12.0^{\prime} \mathrm{W}$ & $0.01-10$ & $8-42$ & 0.3 & 0.2 \\
\hline AP & 52 & $28^{\circ} 46.6^{\prime} \mathrm{N}, 90^{\circ} 15.3^{\prime} \mathrm{W}$ & $0.1-10$ & $11-35$ & 0.2 & 0.2 \\
\hline Peptidase & 82 & $28^{\circ} 57.0^{\prime} \mathrm{N}, 92^{\circ} 05.6^{\prime} \mathrm{W}$ & $0.1-10$ & $30-42$ & 0.1 & 2.2 \\
\hline Peptidase & 83 & $29^{\circ} 05.5^{\prime} \mathrm{N}, 92^{\circ} 06.5^{\prime} \mathrm{W}$ & $1-10$ & $28-37$ & 0.2 & 0.7 \\
\hline Peptidase & 85 & $28^{\circ} 55.9^{\prime} \mathrm{N}, 92^{\circ} 18.9^{\prime} \mathrm{W}$ & $1-10$ & $66-68$ & 0.04 & 4.7 \\
\hline
\end{tabular}




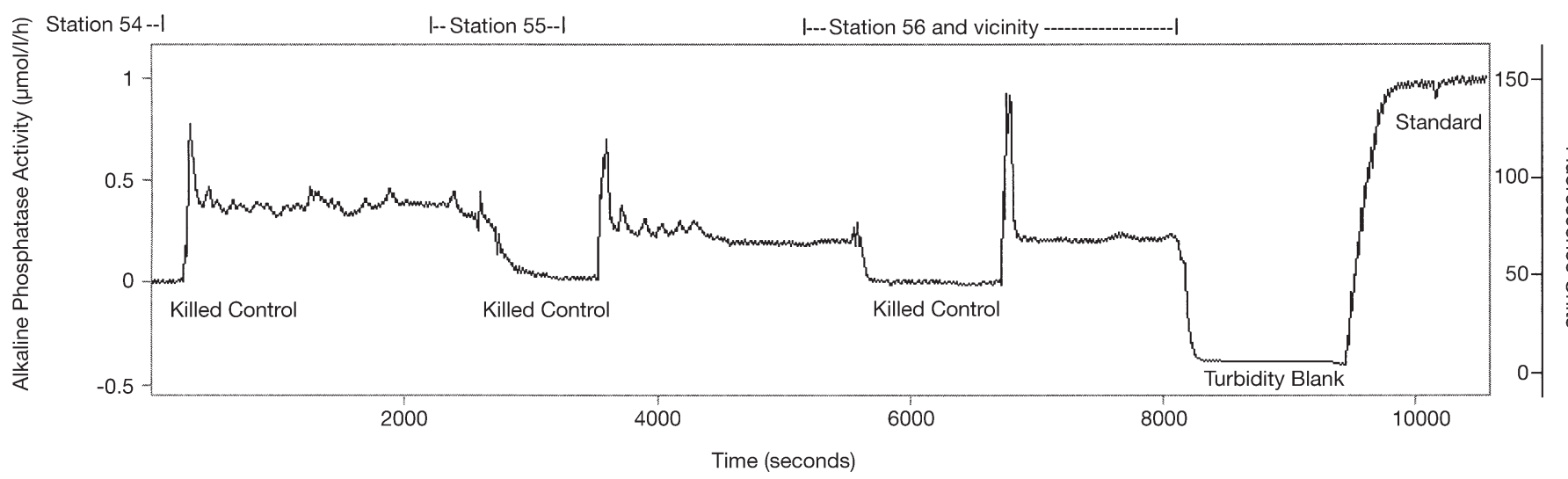

Fig. 3. Annotated alkaline phosphatase data for Transect 1, including killed controls, a turbidity blank, and a $103 \mathrm{nM}$ standard. Calculated alkaline phosphatase activity in $\mu \mathrm{mol}^{-1} \mathrm{~h}^{-1}$ (left axis) and the measured fluorescence (right axis) are shown. The approximate time periods that the ship was at the station are also marked

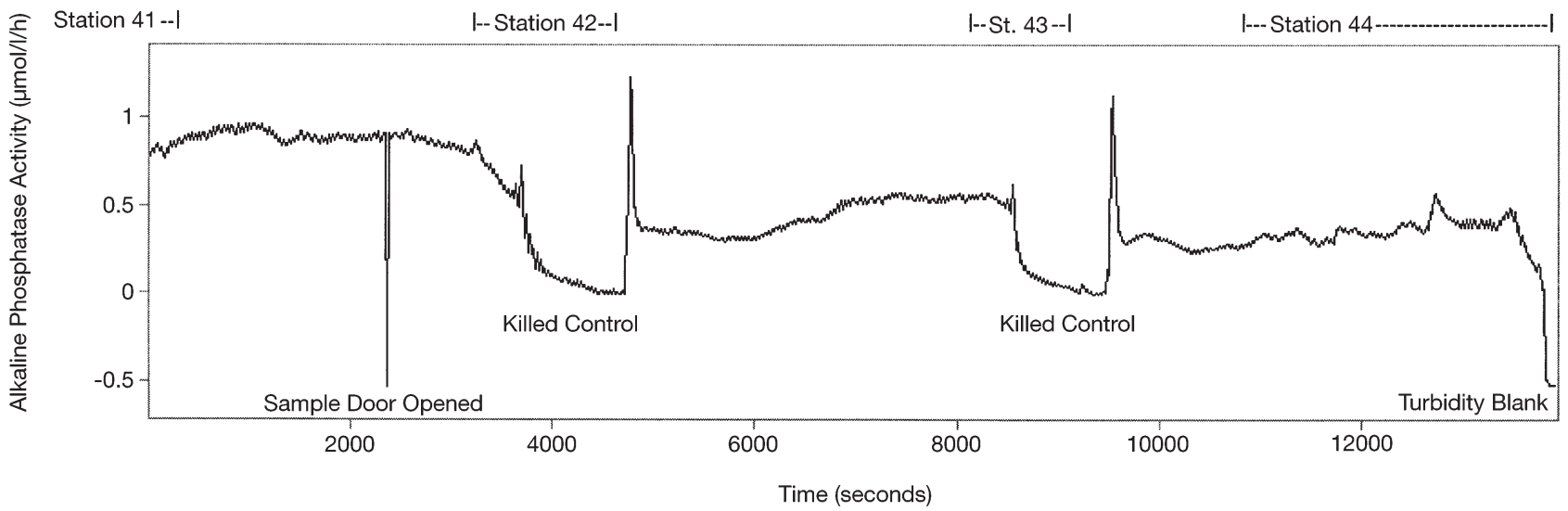

Fig. 4. Annotated alkaline phosphatase data for Transect 2, including killed controls and a turbidity blank. Calculated alkaline phosphatase activity in $\mu \mathrm{mol} \mathrm{l}^{-1} \mathrm{~h}^{-1}$ (left axis) and the measured fluorescence (right axis) are shown. The approximate time periods that the ship was at the station are also marked

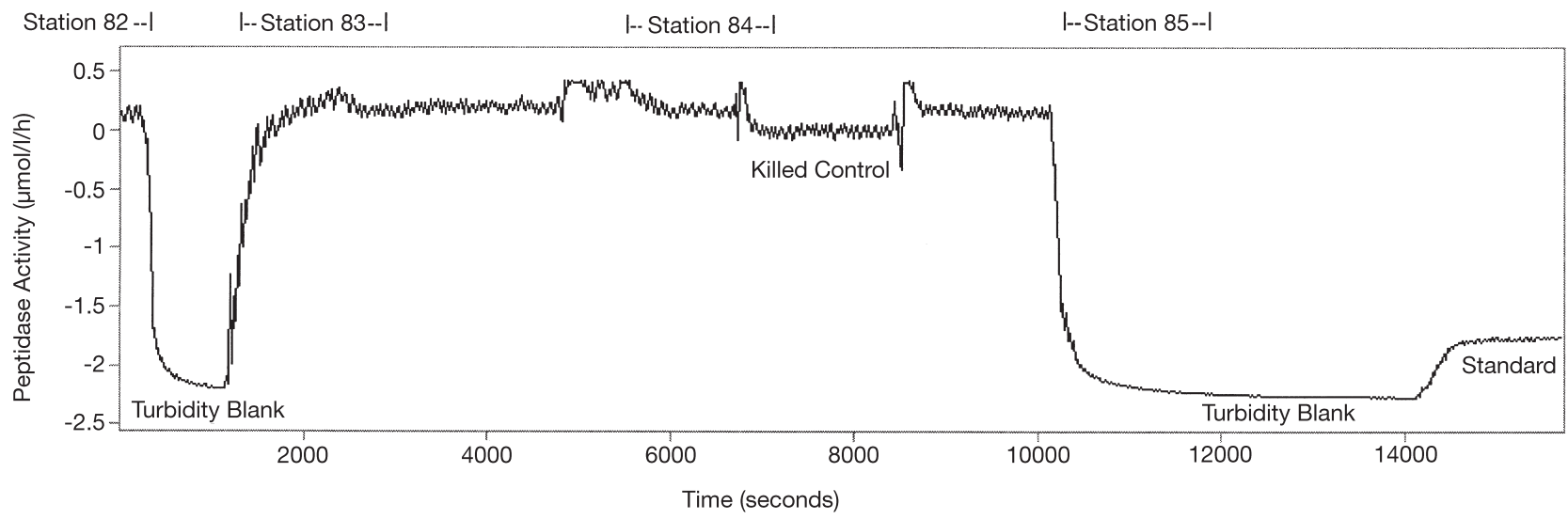

Fig. 5. Annotated peptidase data for Transect 3, including a killed control, turbidity blanks, and a 103 nM standard. Calculated peptidase activity in $\mu \mathrm{mol} \mathrm{l}^{-1} \mathrm{~h}^{-1}$ (left axis) and the measured fluorescence (right axis) are shown. The approximate time periods that the ship was at the station are also marked 
Fig. 1, with the direction of the ship's progress indicated by the arrows. All of the transects illustrated were located on the continental shelf, within the $60 \mathrm{~m}$ isobath.

The annotated fluorescence data produced by phosphatase activity from Transect 1 (Fig. 1) are shown in Fig. 3 (right axis). This figure shows the data record from Stns 54 to 56, as the ship steamed to the northeast over the shelf. The section started (at Stn 54) with a killed control (plus 1.03 $\mu \mathrm{M}$ MUF-P substrate and buffer) that produced a fluorescence reading of around 46 (right axis). This was followed by a sample run with fluorescence values between about 80 and 95, well above the killed control. The initial spike was due to the change from killed control to sample, but some of the smaller spikes may represent real variations in enzyme activity. At present we do not have enough enzyme data or ancillary information to distinguish such spikes from noise (see 'Discussion'). This sample run is followed by another killed control during the stop at Stn 55, which again stabilized at about 46 fluorescence units. Fluorescence values then varied between 66 to 85 (ignoring the initial spike) with numerous spikes early in the record, followed by another killed control at Stn 56, which stabilized at 45. A final segment just beyond Stn 56 was rather constant around a fluorescence value of $\sim 66$, virtually identical to the fluorescence values just before the killed control. The minimum fluorescence value (4) near the end of this transect was for a turbidity blank with sample and buffer as normal, but the substrate was replaced with distilled water. Finally the peak at the end (150) was a $103 \mathrm{nM}$ 4-methylumbelliferone standard which was used to convert fluorescence to activity.

Fig. 3 also shows the phosphatase activity (left axis) calculated for Transect 1 following baseline correction and standardization. Ignoring the large spikes, the killed controls, and the standard (see above), phosphatase activity ranged from nearly $0.40 \mu \mathrm{mol} \mathrm{l}^{-1} \mathrm{~h}^{-1}$ at the western end of the section, near Stn 54, to just below $0.20 \mu \mathrm{mol} \mathrm{l}^{-1} \mathrm{~h}^{-1}$ in most of the central and eastern part of this transect.

Automated phosphatase activities measured along Transect 2 between Stns 41 and 44 (Fig. 1) reached higher levels (Fig. 4) than the previous transect. Fluorescence units are again shown on the right axis and calculated AP activity on the left axis. This transect was both further inshore and closer to the Mississippi Delta than Transect 1 . The initial phosphatase activity in this transect (Fig. 4) was among the highest rates recorded in this study, reaching nearly $1 \mu \mathrm{mol} \mathrm{l}^{-1} \mathrm{~h}^{-1}$. Opening the sample compartment door caused the downward spike in the curve between Stns 41 and 42 . Between Stns 42 and 43 activity increased from about 0.3 to $0.55 \mu \mathrm{mol} \mathrm{l}^{-1} \mathrm{~h}^{-1}$. Finally, between Stns 43 and 44

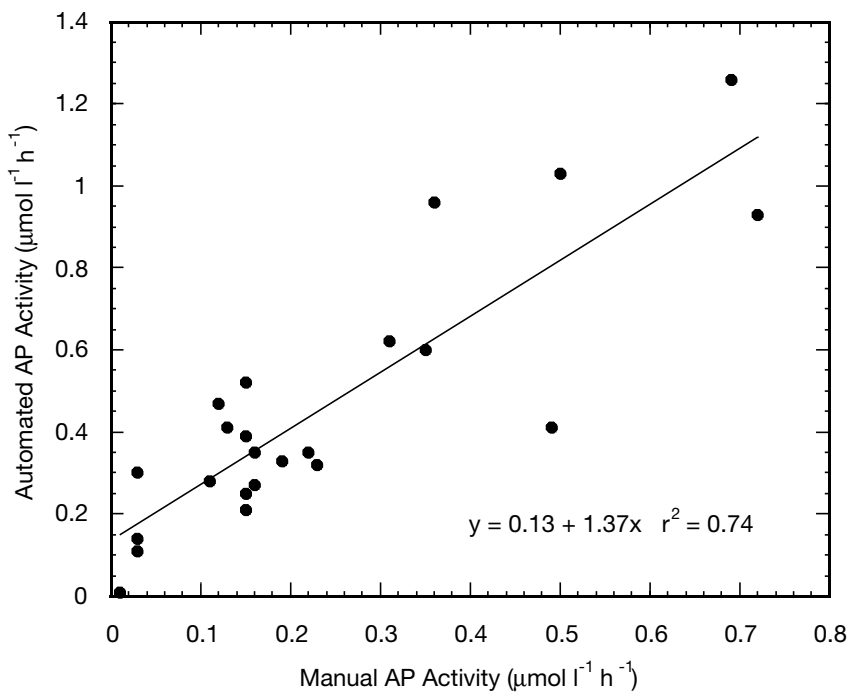

Fig. 6. A comparison of alkaline phosphatase (AP) activity measured at 23 surface stations by both the manual and automated methods using the same $1 \mu \mathrm{M}$ substrate concentration (1.03 $\mu \mathrm{M}$ for the automated measurements). The regression was highly significant $(p<0.001)$

phosphatase activity gradually increased from around 0.3 to $0.4 \mu \mathrm{mol} \mathrm{l}^{-1} \mathrm{~h}^{-1}$.

Fig. 6 shows a comparison of AP activity measured at 23 surface stations by both the manual and automated methods using the same $1 \mu \mathrm{M}$ substrate concentration (1.03 $\mu \mathrm{M}$ for the automated measurements). This comparison included some of the stations from Transects 1 and 2 shown in Fig. 1 and other data from the same cruise. The AP activities measured by manual and automated methods were significantly correlated $\left(\mathrm{r}^{2}=\right.$ 0.74, p < 0.001), but the automated measurements yielded consistently higher activities with a positive $y$-intercept. The longer incubation times used for most of the manual assays compared to the automated assays probably accounted for some of this difference (see 'Discussion').

A continuous record of fluorescence produced by peptidase activity from Transect 3 (Fig. 1) is shown in Fig. 5 (right axis). This record demonstrates that the flow-through method is not limited to phosphatase measurements. This section started toward the middle of the shelf, west of the Atchafalaya outflow at Stn 82, and initially proceeded north before heading west and south to Stn 85. The substrate (Leu-MCA), substrate concentration $(10.3 \mu \mathrm{M})$, incubation time (12.3 $\mathrm{min})$, and excitation and emission wavelengths $(380 \mathrm{~nm} /$ $440 \mathrm{~nm}$ ) were all different from the AP assays in the previous figures. The minimum fluorescence value (42, right axis) shown near the start (Fig. 5) was a turbidity blank followed by a long transect of peptidase activity to Stn 84 with fluorescence values between 935 and 

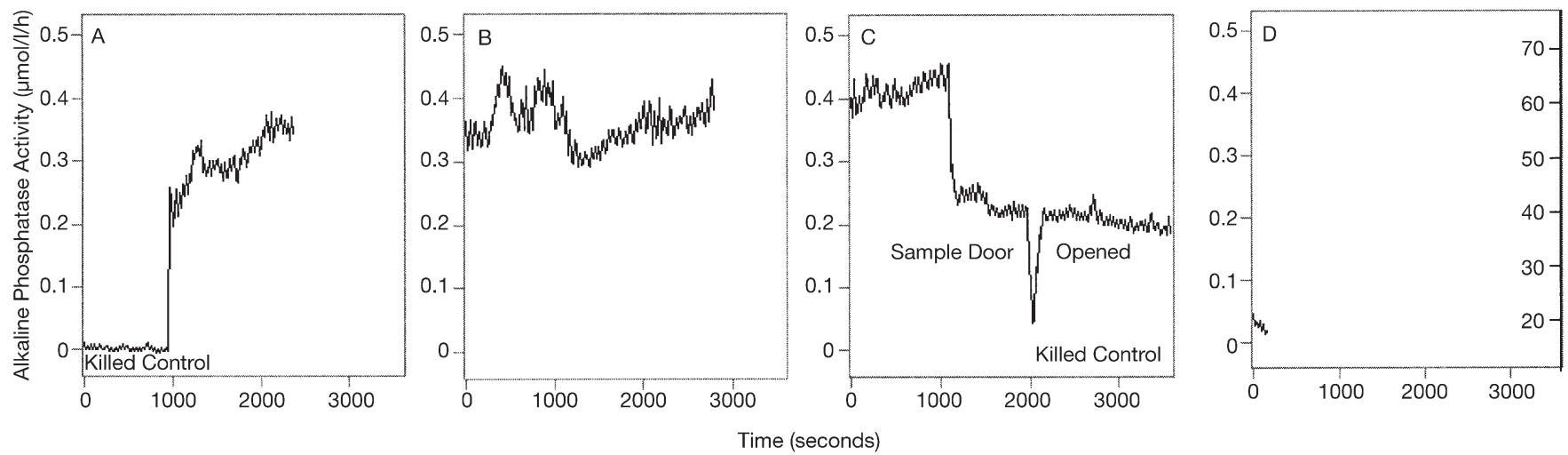

Fig. 7. Annotated alkaline phosphatase data for Lake Travis including killed controls (A to D). Calculated alkaline phosphatase activity in $\mu \mathrm{mol} \mathrm{l}^{-1} \mathrm{~h}^{-1}$ (left axis) and the measured fluorescence (right axis) are shown

1000 (some high values were cut off at 1000 because they had reached the instrument maximum). This was followed by a killed control, which stabilized at about 868 , and another short section of peptidase activity (to near Stn 85) where fluorescence values varied between 920 and 940. The killed control had instrument-attenuated spikes on either side of it which were cut off when they reached fluorescence values of 1000 . Near the end of this transect was another turbidity blank, which reached a minimum value of 21 , followed by a 103 nM 7-amino-4-methylcoumarin standard, which yielded a fluorescence value of 200 .

Though the fluorescence due to enzyme activity was just $10 \%$ above the killed control, the reproducibility of the fluorescence values before and after this control suggests that peptidase activity was present. The average rate of hydrolysis was around $0.2 \mu \mathrm{mol} \mathrm{l}^{-1} \mathrm{~h}^{-1}$ (Fig. 5, left axis). The only spatial trend in peptidase was elevated activity near the middle of the section, which exceeded $0.4 \mu \mathrm{mol} \mathrm{l}^{-1} \mathrm{~h}^{-1}$, but the trace went offscale on the fluorometer. Peptidase activity measured manually on surface samples at Stns 82 to 85 using the same $10 \mu \mathrm{M}$ substrate concentration was generally lower than the automated measurements. Manual activities ranged from $0.03 \mu \mathrm{mol} \mathrm{l} \mathrm{l}^{-1} \mathrm{~h}^{-1}$ (Stn 85) to $0.17 \mu \mathrm{mol} \mathrm{l}^{-1} \mathrm{~h}^{-1}$ (Stn 83), with the remaining stations (Stns 82 and 84) in between at 0.12 and $0.09 \mu \mathrm{mol} \mathrm{l}^{-1}$ $\mathrm{h}^{-1}$, respectively. Stn 83 was the only one where peptidase activity was measured directly at the station (Fig. 5) by both methods, both activities were identical $\left(0.17 \mu \mathrm{mol} \mathrm{l}^{-1} \mathrm{~h}^{-1}\right)$. The background fluorescence for peptidase measurements was much higher than for phosphatase because the substrate concentration was 10 times higher. Clearly, further optimization of the peptidase assay is needed to improve the signal-tonoise ratio (see 'Discussion').

We also tested this flow-through system, on Lake Travis, as described above. AP activity was measured at the substrate concentration and wavelengths described above for AP. However, the transect along the Sandy Creek arm of the lake was divided into 4 different data files (Fig. 7A to D), with about a 2 min gap between each, to make sure that there was no chance of data loss during this initial test. The fluorescence (right axis) of the initial killed control was 12 (Fig. 7A), which was followed by sample fluorescence values from 40 to 70 (Fig. 7B,C) as the boat proceeded along the arm of the lake. The killed control at the end of the run (Fig. 7C, $1100 \mathrm{~s}$ ) was initially significantly higher than the original killed control (Fig. 7A), with a starting fluorescence of 43. However, it gradually declined to about 15 (Fig. 7D), similar to the initial value in Fig. 7A. Most of the decline occurred during the short 2 min transition between the computer files represented by Fig. $7 \mathrm{C}, \mathrm{D}$. The downward spike in the middle of Fig. $7 \mathrm{C}$ occurred when the door to the sample compartment was opened. Assuming a nearly flat baseline, the phosphatase activity (Fig. 7A to D) ranged from about 0.22 to $0.45 \mu \mathrm{mol} \mathrm{l} \mathrm{l}^{-1} \mathrm{~h}^{-1}$, generally increasing along the transect though with some variation in midtransect. No manual measurements of AP activity were made on Lake Travis samples at the same time, though previous measurements made in June and July of 1990 with a $0.1 \mu \mathrm{M}$ substrate concentration yielded activi-

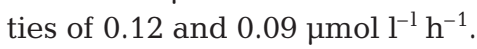

\section{DISCUSSION}

This study demonstrates that in situ microbial ectoenzyme activities can be measured continuously in aquatic environments in near real-time. Using this method we may be able to observe fine-scale spatial or temporal variations in enzyme activity. Therefore we can hope to map surface enzyme activity on the same scale of resolution as other properties, such as temper- 
ature, salinity, or in vivo fluorescence. This method works for lakes, and estuarine and coastal waters, though it is currently insufficiently sensitive for most studies in the open ocean. However, future improvements in sensitivity, through the use of fiber optics and other enhancements, could extend its application to oligotrophic waters as well (see below).

This study provides one of the first examples of a continuous biological rate measurement performed in a marine or freshwater environment. This method could be useful not only in mapping surface properties but also for continuous vertical profiling and for process monitoring. It could be deployed for vertical profiling using a constant incubation temperature, if the activity was corrected for the changing sample temperatures using appropriate $Q_{10}$ values. An example of process monitoring would be continuous monitoring of the flow past a specific point, such as the wastewater effluent from a treatment plant. While we concentrated on phosphatase, which has previously been well documented in the study area (Ammerman 1992, Kim 1996), we have also shown that LAP activity can also be measured with this system.

AP activities measured by both automated and manual methods were highly correlated (Fig. 6), though the automated activities were consistently higher. Much of the difference was probably due to the incubation time, it is difficult to manually process the samples fast enough to limit the incubation time to less than $5 \mathrm{~min}$, while all the automated assays reported were incubated for only $4.5 \mathrm{~min}$. However, using a $1 \mu \mathrm{M}$ substrate concentration with high AP activities, manual incubation times longer than 5 min may limit the maximal activity to rates less than $1 \mu \mathrm{mol} \mathrm{l}^{-1} \mathrm{~h}^{-1}$. In addition, the depth of sampling for the automated assays was usually $1 \mathrm{~m}$ or more below that for the manual samples. There are large vertical salinity gradients at some stations in this region, and the additional depth of the automated AP samples may also explain some of the difference in activities. There is no evidence, however, that this additional depth should consistently increase the automated AP activity measurements. Shaking of samples during incubation can increase the activity measured with manual assays (Hoppe 1993). Therefore, another potential explanation for the higher activity of the automated assays was the greater mixing of the samples during the assay as compared with the manual assays. Since our manual assays were not shaken during incubation we cannot rule this out; however, they were mixed vigorously at the start of the assay.

Surface peptidase activities measured by manual methods at Stns 82 to 85 using a $10 \mu \mathrm{M}$ substrate concentration were generally lower than automated measurements in the same area, though both types of assays were conducted directly at only Stn 83. In Lake
Travis, manual AP measurements were about $25 \%$ of the maximum values measured with the automated system; however, the 2 types of measurements were not directly comparable in time, space, or substrate concentration.

There are several methodological issues with the automated method that remain unresolved. First, the baseline, as measured by the fluorescence produced by a killed control, sometimes increased over time. Though this can be corrected by subtracting a sloping baseline from the fluorescence curve, it does increase the uncertainty of the measurements. This problem was most noticeable in the Lake Travis data (Fig. 7A to D), though the baseline eventually returned to nearinitial values in Fig. 7D and little correction was needed. The increasing baseline may be due to breakdown of the stock substrate solution during the assay period, though the solution was kept in an ice bath and shielded from light during this period.

A second issue is the spikes seen in most of the automated enzyme records (Figs. 3 to $5 \& 7$ ). All the large spikes were artifacts of the method, usually air bubbles that were too large to be removed by the debubbler; these bubbles were introduced by changes in the solutions. These large spikes were most common when switching from a sample to a killed control and especially back again during a transect of activity measurements. Though they appear less prominent in the transect of peptidase activity (Fig. 5), the spikes on either side of the killed control were cut off when the top end of the instrument range was reached (1000 fluorescence units). Numerous small spikes were also seen in some of enzyme activity measurements (such as in the left half of Fig. 3); it is unclear whether they are real variations in activity or an artifact of the method. The steepness and frequency of some of these spikes suggest that they may be artifacts, such as the series of small spikes following the large one when leaving Stn 55 (Fig. 3). Power surges can probably be ruled out because of the UPS. However, some of the small spikes could also represent 'hot-spots' of activity, perhaps patches of highly active cells or some other type of fine-scale structure.

The best way to minimize the large spikes would be to improve the transitions between blanks and samples. In this study they were made by hand, but improved plumbing should prevent the formation of such large bubbles. The response time of the system could also be improved by decreasing the volume and thus the path length of the flow cell. This would decrease the response time to changes in activity by decreasing the residence time of the sample in the flow cell, though it already flushes every $15 \mathrm{~s}$. The drawback to this would be a decrease in sensitivity. As we get more experience with the method and are able to 
couple it with continuous underway measurements of in vivo fluorescence and other parameters, we should develop a better understanding of the meaning of these spikes. Unfortunately, no other underway measurements were available aboard the RV 'Longhorn' during this study.

A third important issue is the sensitivity of the automated assay. From Fig. 6 the automated AP assay would appear to be at least as sensitive as the manual assay method, and probably more sensitive. Though surface water temperatures during the NECOP cruise were $30^{\circ} \mathrm{C}$ or above (Table 1) and contributed to high AP activity, normal enzyme $Q_{10}$ values near 2 suggest that activity should still be readily measurable at lower temperatures with the automated method. This was true of the AP measurements on Lake Travis. Sensitivity of the automated method could be increased by increasing the substrate concentration, increasing the incubation time, or by increasing the volume of the flow cell.

Manual AP activity measured with $1 \mu$ M MUF-P substrate was $78 \%$ of the activity with $10 \mu \mathrm{M}$ substrate. Though the ratio of signal (sample fluorescence) to noise (killed control fluorescence) for the automated AP assays was ample, using a $10 \mu \mathrm{M}$ substrate concentration could have further increased it. The $4.5 \mathrm{~min}$ incubation time worked well for AP measurements near the Mississippi plume, though this was increased to $12.3 \mathrm{~min}$ for peptidase measurements and some AP measurements west of Atchafalaya Bay. Increasing the incubation time is a relatively easy way to increase sensitivity where necessary; however, it increases the amount of plumbing required. In areas with extreme spatial variability, like the Mississippi plume, an excessive incubation period may limit the maximum rate of activity that can be measured (see above). We used a $0.75 \mathrm{ml}$ flow cell with a $10 \mathrm{~mm}$ path length. Additional sensitivity might be gained with a longer path length cell (this would also require a different type of cell holder), which would probably hold a larger volume. Such additional sensitivity would come at the expense of a longer response time for the system as discussed above. Improvements in instrumentation, such as the increased use of fiber optics, should also increase sensitivity. As the sensitivity is increased, the range of the automated assay system will be increasingly extended into more oligotrophic regions.

The automated peptidase measurements were near the limits of detection for the system as constructed. Though the signal to noise ratio was much less than for phosphatase, the measured peptidase activity was in the low end of the AP activity range. Thus, while alkaline phosphatase activity was readily measured with our current system, further optimization of the peptidase assay is required to increase the signal to noise ratio. This would include the modifications discussed above as well as others.

While the limited data presented here are largely to demonstrate the method, the results are consistent with other available information. The inflowing surface water from the Mississippi River has a high DIN: $\mathrm{PO}_{4}{ }^{3-}$ ratio during high-flow periods which normally occur in winter and spring but also included July of 1990 and 1993 (Ammerman 1992, Walker et al. 1994, Lohrenz et al. 1999). The resulting phosphorus deficiency results in high alkaline phosphatase activity and rapid uptake rates of inorganic phosphate in the highly productive intermediate salinity area to the west of the river mouth (Ammerman 1992, Kim 1996). This was consistent with our results for Transect 2 (Fig. 1, Stns 41 to 44), which was the closest to the river mouth, had the highest average DIN:PO${ }^{3-}$ ratio, and showed the highest automated AP activity. Nutrient bioassay studies also show phosphorus limitation of phytoplankton and bacterial growth in and near the Mississippi plume region during the spring and early summer (Smith \& Hitchcock 1994, Pomeroy et al. 1995).

The peptidase measurements (Fig. 5) also demonstrate that other microbial-cell surface enzymes can also be measured with this continuous underway system. Our peptidase data were too limited to see any trends, but peptidases and proteases are usually among the easiest ectoenzymes to measure in natural aquatic environments, since they often have the highest reported activities. In studies of marine aggregates (Smith et al. 1992), 'protease' activity, measured with the same peptidase substrate we used, was always the first or second most active of a series of ectoenzymes, phosphatase was the other highly active enzyme. Likewise in Australian ox-bow lakes, aminopeptidase and phosphatase were the most active of a series of ectoenzymes assayed (Boon 1991). Foreman et al. (1998) showed that phosphatase and peptidase activities in the Maumee River in Ohio had $V_{\max }$ values second and third only to esterase activity.

Chrost $(1991,1994)$ found that the highest peptidase $V_{\max }$ values during the decline of spring and summer phytoplankton blooms in a eutrophic German lake, when algal cells were decaying. Peptidases and proteases have been repeatedly measured by several different methods in a variety of marine coastal environments, including the Belgian coast of the North Sea (Billen 1991) and the mesotrophic Southern California Bight (Hollibaugh \& Azam 1983, Rosso \& Azam 1987). LAP was also measured extensively in the Southern Ocean, the subtropical North Pacific, and the equatorial Pacific (Christian \& Karl 1995). Therefore, peptidases and proteases should be good candidates for further development of continuous-flow assays in the future. 
This study demonstrates the continuous measurement of microbial ectoenzyme activities in a variety of aquatic environments. Particularly when coupled with other continuous biomass or other underway measurements, this could become a powerful technique for examining microbial metabolism in aquatic environments. This method can be used for the spatial evaluation of nutrient limitation, as shown briefly here, but may also find other uses such as mapping microbial metabolic rates or responses to pollutants.

Acknowledgements. This research was undertaken with support from the Coastal Ocean Program Office of the National Oceanic and Atmospheric Administration through Grant No. NA90AA-D-SG689 to the Texas A\&M University Sea Grant College Program. A supplement to National Science Foundation grant OCE90-19415 provided support for a summer teacher internship for W.B.G. under the Texas A\&M University STARS program. We thank Mark Spears for the original plumbing design of the apparatus, James Patek (formerly of the Lower Colorado River Authority) for arranging for the use of a boat and driver on Lake Travis, and Jin-Seok Kim and Rosa Sada Ruvalcaba for assistance with the sampling on Lake Travis. We also thank the captain and crew of the RV 'Longhorn' for their cooperation and assistance with our sampling requirements during the NECOP cruise. Martha MacRae performed the manual enzyme assays and assisted with other tasks on the NECOP cruise, as well as analyzing ancillary samples from Lake Travis. Dale Dong (NOAA/ GLERL) provided hydrographic data from the NECOP cruise, Terry Whitledge (U. Alaska) provided nutrient data and assisted with the chlorophyll data, and James Cotner (U. Minnesota) provided bacterial abundance information. Darin Case and Yao-Tsai Lo helped with figure preparation, and Lisa Campbell, Jay Pinckney, and 4 anonymous reviewers suggested improvements on the manuscript. Dedicated to the memory of Carl J. Lorenzen whose work inspired this study.

\section{LITERATURE CITED}

Ammerman JW (1991) Role of ecto-phosphohydrolases in phosphorus regeneration in estuarine and coastal ecosystems. In: Chrost RJ (ed) Microbial enzymes in aquatic environments. Springer-Verlag, New York, p 165-186

Ammerman JW (1992) Seasonal variation in phosphate turnover in the Mississippi River Plume and the Inner Gulf Shelf: rapid summer turnover. In: Bright TJ (ed) Proceedings of the 1991 NECOP Synthesis Workshop. Texas A\&M Sea Grant, Galveston, p 69-75

Ammerman JW (1993) Microbial cycling of inorganic and organic phosphorus in the water column. In: Kemp PF, Sherr BF, Sherr EB, Cole JJ (eds) Handbook of methods in aquatic microbial ecology. Lewis Publishers, Boca Raton, p 649-660

Ammerman JW, Glover WB, Sada Ruvalcaba RH, MacRae MJD (1995) Continuous underway measurement of microbial enzyme activities in surface waters of the Mississippi River plume and the Louisiana shelf. In: Atwood DK, Graham WF, Grimes CB (eds) Nutrient-enhanced coastal ocean productivity. Proceedings of 1994 Synthesis Workshop. Louisiana Sea Grant College Program, Baton Rouge, p 1-8
Azam F (1998) Microbial control of oceanic carbon flux: the plot thickens. Science 280:694-696

Berges JA, Falkowski PG (1996) Cell-associated proteolytic enzymes from marine phytoplankton. J Phycol 32:566-574

Billen G (1991) Protein degradation in aquatic environments. In: Chrost RJ (ed) Microbial enzymes in aquatic environments. Springer-Verlag, New York, p 123-143

Boon PI (1991) Enzyme activities in billabongs of Southeastern Australia. In: Chrost RJ (ed) Microbial enzymes in aquatic environments. Springer-Verlag, New York, p 286-297

Campbell L, Liu H, Nolla HA, Vaulot D (1997) Annual variability of phytoplankton and bacteria in the subtropical North Pacific Ocean at Station ALOHA during the 1991-1994 ENSO event. Deep-Sea Res I 44:167-192

Christian JR, Karl DM (1995) Bacterial ectoenzymes in marine waters-activity ratios and temperature responses in three oceanographic provinces. Limnol Oceanogr 40: 1042-1049

Christian JR, Karl DM (1998) Ectoaminopeptidase specificity and regulation in Antarctic marine pelagic microbial communities. Aquat Microb Ecol 15:303-310

Chrost RJ (1990) Microbial ectoenzymes in aquatic environments. In: Overbeck J, Chrost RJ (eds) Aquatic microbial ecology: biochemical and molecular approaches. Springer-Verlag, New York, p 47-78

Chrost RJ (1991) Environmental control of synthesis and activity of aquatic microbial ectoenzymes. In: Chrost RJ (ed) Microbial enzymes in aquatic environments. Springer-Verlag, New York, p 29-59

Chrost RJ (1994) Microbial enzymatic degradation and utilization of organic matter. In: Overbeck J, Chrost RJ (eds) Microbial ecology of Lake Plußsee. Springer-Verlag, New York, p 118-174

Chrost RJ, Krambeck HJ (1986) Fluorescence correction for measurements of enzyme activity in natural waters using methylumbelliferyl-substrates. Arch Hydrobiol 106:79-90

Delmas D, Legrand C, Bechemin C, Collinot C (1994) Exoproteolytic activity determined by flow-injection analysis - its potential importance for bacterial-growth in coastal marine ponds. Aquat Living Resour 7:17-24

Foreman CM, Franchini P, Sinsabaugh RL (1998) The trophic dynamics of riverine bacterioplankton: relationships among substrate availability, ectoenzyme kinetics, and growth. Limnol Oceanogr 43:1344-1352

Gonzalez-Gil S, Keafer BA, Jovine RVM, Aguilera A, Lu SH, Anderson DM (1998) Detection and quantification of alkaline phosphatase in single cells of phosphorus-starved marine phytoplankton. Mar Ecol Prog Ser 164:21-35

Hobbie JE, Daley RJ, Jasper S (1977) Use of Nuclepore filters for counting bacteria by fluorescence microscopy. Appl Environ Microbiol 33:1225-1228

Hollibaugh JT, Azam F (1983) Microbial degradation of dissolved proteins in sea water. Limnol Oceanogr 28: $1104-1116$

Hoppe HG (1983) Significance of exoenzymatic activities in the ecology of brackish water: measurements by means of methylumbelliferyl-substrates. Mar Ecol Prog Ser 11: 299-308

Hoppe HG (1993) Use of fluorogenic model substrates for extracellular enzyme activity (EEA) measurement of bacteria. In: Kemp PF, Sherr BF, Sherr EB, Cole JJ (eds) Handbook of methods in aquatic microbial ecology. Lewis Publishers, Boca Raton, p 423-431

Kim JS (1996) Phosphorus limitation in the Mississippi River Plume (MRP) and Louisiana Shelf (LS) during May 1992. MS thesis, Texas A\&M University, College Station 
Lohrenz SE, Fahnenstiel GL, Redalje DG, Lang GA, Dagg MJ, Whitledge TE, Dortch Q (1999) The interplay of nutrients, irradiance, and mixing as factors regulating primary production in coastal waters impacted by the Mississippi River plume. Cont Shelf Res 19:1113-1141

Lorenzen CJ (1966) A method for the continuous measurement of in vivo chlorophyll concentration. Deep-Sea Res 13:213-222

Martinez J, Azam F (1993a) Aminopeptidase activity in marine chroococcoid cyanobacteria. Appl Environ Microbiol 59:3701-3707

Martinez J, Azam F (1993b) Periplasmic aminopeptidase and alkaline phosphatase activities in a marine bacterium: implications for substrate processing in the sea. Mar Ecol Prog Ser 92:89-97

Martinez J, Smith DC, Steward GF, Azam F (1996) Variability in ectohydrolytic enzyme activities of pelagic marine bacteria and its significance for substrate processing in the sea. Aquat Microb Ecol 10:223-230

Morel A, Antoine D, Babin M, Dandonneau Y (1996) Measured and modeled primary production in the northeast Atlantic (EUMELI JGOFS program): the impact of natural variations in photosynthetic parameters on model predictive skill. Deep-Sea Res I 43:1273-1304

Olson RJ, Sosik HM (1999) An in situ flow cytometer for the optical analysis of individual particles in seawater. ASLO Aquat Sci Mtg Abs Book, p 133

Perry MJ (1972) Alkaline phosphatase activity in subtropical Central North Pacific waters using a sensitive fluorometric method. Mar Biol 15:113-119

Pfeiffer HF, Waldhoff H, Worsfold PJ, Whiteside IRC (1992) Automated flow-injection procedures for the determination of hydrolytic enzymes in bioreactor preparations. Chromatographia 33:49-52

Pomeroy LR, Sheldon JE, Sheldon WM Jr, Peters F (1995)

Editorial responsibility: Jed Fuhrman (Contributing Editor), Los Angeles, California, USA
Limits to growth and respiration of bacterioplankton in the Gulf of Mexico. Mar Ecol Prog Ser 117:259-268

Rabalais NN, Wiseman WJ, Turner RE, SenGupta BK, Dortch Q (1996) Nutrient changes in the Mississippi River and system responses on the adjacent continental shelf. Estuaries 19:386-407

Rosso AL, Azam F (1987) Proteolytic activity in coastal oceanic waters: depth distribution and relationship to bacterial populations. Mar Ecol Prog Ser 41:231-240

Sieracki CK, Sieracki ME, Yentsch CS (1998) An imaginginflow system for automated analysis of marine microplankton. Mar Ecol Prog Ser 168:285-296

Sinsabaugh RL, Findlay S, Franchini P, Fisher D (1997) Enzymatic analysis of riverine bacterioplankton production. Limnol Oceanogr 42:29-38

Smith DC, Simon M, Alldredge A, Azam F (1992) Intense hydrolytic enzyme activity on marine aggregates and implications for rapid particle dissolution. Nature 359: 139-142

Smith SM, Hitchcock GL (1994) Nutrient enrichments and phytoplankton growth in the surface waters of the Louisiana Bight. Estuaries 17:740-753

Steward GF, Azam F (1999) Bromodeoxyuridine as an alternative to ${ }^{3} \mathrm{H}$-thymidine for measuring bacterial productivity in aquatic samples. Aquat Microb Ecol 19:57-66

Strickland JDH, Parsons TR (1972) A practical handbook of seawater analysis. Bull Fish Res Board Can 167

Turner RE, Rabalais NN (1994) Coastal eutrophication near the Mississippi River delta. Nature 368:619-621

Walker ND, Fargion GS, Rouse LJ, Biggs DC (1994) The great flood of summer 1993: Mississippi River discharge studied. EOS 75:414-415

Whitledge TE, Malloy SC, Patton CJ, Wirick CD (1981) Automated nutrient analysis in seawater, Formal report 51398. Brookhaven National Laboratory, Upton, NY

Submitted: April 23, 1999; Accepted: December 15, 1999 Proofs received from author(s): July 4, 2000 